\title{
Growing a garden community: A film review
}

\author{
Review by Brian Raison, Ohio State University \\ Extension*
}

Review of the documentary film $A$ Garden Experience: Growing Organic, directed by Nancy Bentley and produced by Nancy Bentley and John Atkinson. (2018). Film's website: https://www.amazon.com/Garden-ExperienceGrowing-Organic/dp/B0812C8B7Y/

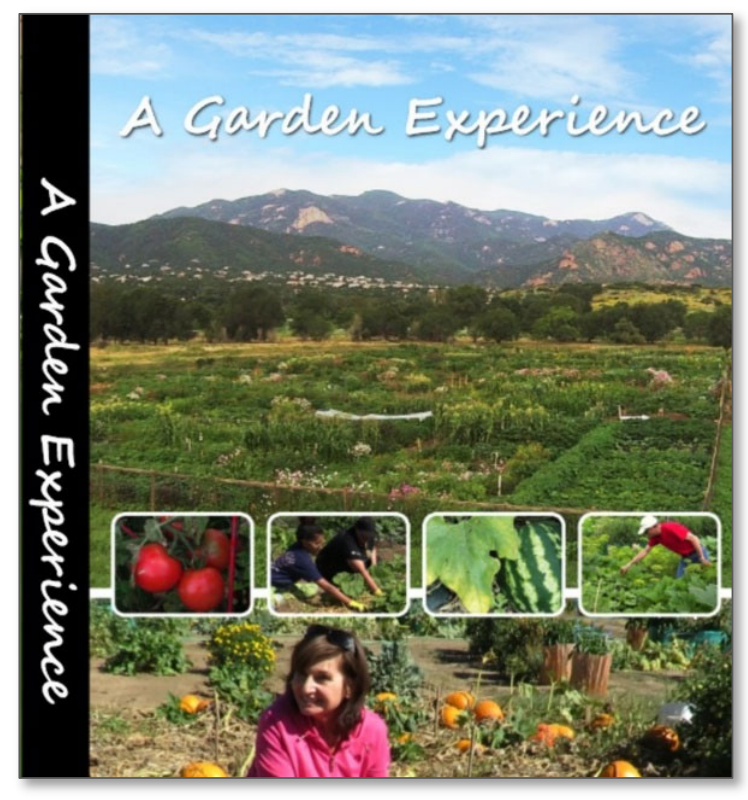

Submitted February 18, 2020 / Published online April 8, 2020

Citation: Raison, B. (2020). Growing a garden community: A film review. Journal of Agriculture, Food Systems, and Community Development, 9(3), 325-326. https://doi.org/10.5304/jafscd.2020.093.009

Copyright (C) 2020 by the Author. Published by the Lyson Center for Civic Agriculture and Food Systems. Open access under CC-BY license.

"It's not about the vegetables. It's about community."

$\mathrm{A}_{\text {food group, garden club, or association meet- }}^{\text {re looking for some inspiration for a local }}$

* Brian Raison, Associate Professor, OSU Extension; 100 Fairground Road; Xenia, OH 45385 USA; raison.1@,osu.edu. For 24 years, Brian Raison has served Ohio State University as an extension educator, field specialist, and associate professor. He works extensively in local food systems, strategic planning, and capacity building. He volunteers with community-based nonprofits, and carries on heirloom gardening traditions learned from his grandfathers over 40 years ago. ing? Would you like to set the stage of an eventperhaps a food summit or a gardening or agricultural conference-with a positive message about food and community? A Garden Experience: Growing Organic, a film about an organic community garden project in Colorado, may provide that inspiration. As one of the participating gardeners says, "It's not about the vegetables. It's about community."

Last summer, I attended the inaugural Germinate International Film Festival ${ }^{1}$ in Hillsboro, Ohio (Aug. 16-19, 2019). There, I happened to sit in on a viewing and discussion of $A$ Garden Experience:

\footnotetext{
${ }^{1}$ The festival itself was conceived by Dr. Brooke Beam, agriculture and natural resources and community development educator with Ohio State University Extension. The selected films that were screened came from Canada, India, Italy, Mexico, the Netherlands, Senegal, and the United Kingdom; from the U.S., they came from Arkansas, Alabama, California, Colorado, Florida, Illinois, Kansas, Kentucky, Maryland, Missouri, Montana, New York, North Carolina, Ohio, and Pennsylvania. Filmmakers attended from California, Colorado, Kentucky, Montana, New York, and Ohio.
} 
Growing Organic. Filmmakers Nancy Bentley and John Atkinson invested a year at the Bear Creek Community Garden, capturing not only the physical inputs and outcomes of running a community garden in southern Colorado, but also the stories behind the gardeners themselves.

This inspiring short documentary compresses a year in the life of a large organic community garden into 28 minutes. It shows the struggles and joys of volunteering, spring tilling, planting, board meetings, potlucks, wildlife sightings, and harvesting. But the real beauty comes as we peer into the lives of a small group of organic gardeners who, together, overcome the challenges and share the rewards of the experience. The filmmakers note that the message is clear: "If these determined gardeners in southern Colorado can succeed in going organic, so can other gardening enthusiasts everywhere as well."

It must be noted, and the filmmakers agree, that although organic food options may provide positive health, nutrition, and environmental benefits, organic foods and products can be significantly more expensive than going conventional. In response, the film posits an alternative: tend your own organic garden. This, of course, is easier said than done, and that "how-to" is really not addressed. Hence, I suggest setting aside the organic vs. conventional growing, and focusing on the community aspect of the film. That is where I found great inspiration.

As a community development educator for Ohio State's Extension service, I saw a dozen reminders of why I do this work. I was moved to both laughter and tears by stories of gophers eating sweet potatoes, and how this garden was helping to heal people, both mentally and physically.

I was inspired and reminded of the opportunities to connect with diverse populations who bring such strength and beauty to whatever undertaking is at hand. And I began thinking about how I could simultaneously discover, again in my work, a greater understanding of this world and how my small part might result in positive action and outcomes, such as seen in this garden.

If you watch this film, you will be inspired and heartened by coming to know the participants. You will think differently about the communities where you work. Your respect for people and their stories in your work will grow. If you set aside the organic vs. conventional piece and simply focus on the community, this film will inspire you. Whether watching with a group, or alone in your office, give it a viewing. Share it at your next meeting. You'll be glad you did. 